\title{
Gonadotrophin-responsiveness of granulosa cells from bone morphogenetic protein 15 heterozygous mutant sheep
}

\author{
Kenneth P McNatty, Derek A Heath, Norma L Hudson, Stan Lun ${ }^{1}$, Jennifer L Juengel ${ }^{2}$ \\ and Lloyd G Moore ${ }^{2}$ \\ Victoria University of Wellington, Wellington 6140, New Zealand, ${ }^{1}$ Mesynthes Ltd, Lower Hutt 5040, New Zealand \\ and ${ }^{2}$ AgResearch, Invermay Agricultural Centre, Mosgiel 9053, New Zealand \\ Correspondence should be addressed to KPMcNatty; Email: kenneth.mcnatty@vuw.ac.nz
}

\begin{abstract}
The aim of this study was to test the hypothesis that the higher ovulation-rate in ewes heterozygous for a mutation in bone morphogenetic protein 15 (BMP15; Fec $\mathbf{I}^{\prime}$; otherwise known as Inverdale or I+ ewes) is due to granulosa cells developing an earlier responsiveness to $\mathrm{LH}$, but not FSH. To address this hypothesis, granulosa cells were recovered from every individual nonatretic antral follicle ( $>2.5 \mathrm{~mm}$ diameter) from I+ and wild-type $(++)$ ewes during anoestrus and the luteal and follicular phases and tested for their responsiveness to FSH and human chorionic gonadotrophin (hCG; a surrogate for LH). For the FSH receptor (FSHR) binding study, granulosa cells were harvested in three separate batches from all antral follicles $(\geq 2.5 \mathrm{~mm}$ diameter) from $\mathrm{I}+$ and ++ ewes. Using a highly-purified ovine FSH preparation, no evidence was found to suggest that I+ ewes have a higher ovulation-rate due to enhanced sensitivity of granulosa cells to FSH with respect to cAMP responsiveness or to their FSHR binding characteristics (equilibrium $K_{d}$ or $B_{\text {max }}$ ). By contrast, a significantly higher proportion of follicles from I+ ewes contained granulosa cells responsive to hCG. The higher proportion was due to cells from more small follicles (i.e. $>2.5-4.5 \mathrm{~mm}$ diameter) developing a response to $\mathrm{hCG}$. It is concluded that the mutation in the BMP15 gene in I+ ewes leads to an earlier acquisition of LH responsiveness by granulosa cells in a greater proportion of follicles and this accounts for the small but significantly higher ovulation-rate in these animals.

Reproduction (2009) 138 545-551
\end{abstract}

\section{Introduction}

A number of sheep breeds have been identified with point mutations in an oocyte derived growth factor, bone morphogenetic protein 15 (BMP15; Galloway et al. 2000, Hanrahan et al. 2004, Bodin et al. 2007, Martinez-Royo et al. 2008, Monteagudo et al. 2009). In general, animals heterozygous for the mutations in BMP15 have a higher mean ovulation rate than their respective wild-type controls. By contrast, those homozygous for the BMP15 mutation are infertile due to follicular growth being impaired from the primary stage of development. Sheep known as the Hanna line (allele known as Fec $\mathrm{X}^{\mathrm{H}}$ ) have a mutation in the BMP15 gene that introduces a stop codon and thus a truncation at the twenty-third amino acid (AA) in the $125 \mathrm{AA}$ sequence of mature BMP15 (Galloway et al. 2000). In Inverdale ewes (allele known as Fec $X^{\prime}$ ), the point mutation in the BMP15 gene results in valine being substituted by aspartic acid at AA number 31 of the mature BMP15 protein. Since homozygous Inverdales have an identical ovarian phenotype to that of homozygous Hanna ewes (Galloway et al. 2000), it is reasonable to assume that the overall level of BMP15 or the biological activity of the protein secreted by oocytes is lower in heterozygous Inverdale ewes than in wildtype ewes. Further evidence to support this has been obtained from studies with transfected HEK 293 cells where human BMP15 with the Inverdale mutation was co-expressed with wild-type human GDF9. Secretions of both BMP15 and GDF9 were reduced (see Moore \& Shimasaki 2005 for review). However, it seems unlikely that a reduction in both BMP15 and GDF9 is the cause of increased fertility in heterozygous Inverdale ewes since evidence from immunisation studies in wild-type ewes, where antibodies that recognised BMP15 but not GDF9 were generated, suggests that a reduction in secreted bioactive BMP15 alone can lead to increases in ovulation rates and litter size similar to that in heterozygous Inverdale animals (Juengel et al. 2002, McNatty et al. 2006). In vitro studies with rat granulosa cells have shown that BMP15 can inhibit expression of $\mathrm{FSH}$ receptor $(F S H R)$ mRNA as well as $\mathrm{FSH}$-induced expression of STAR, P450scc, 3 $\beta$-hydroxysteroid dehydrogenase, inhibin subunits and LHR (Shimasaki et al. 2004). The evidence from in vitro studies with 
granulosa cells from Inverdale ewes was equivocal with regard to whether BMP15 inhibits the actions of FSH (Shackell et al. 1993). The reason for this was that the FSH preparation used in these studies, namely NIADDKovine FSH (oFSH)-17, contained a measurable level of biologically active $\mathrm{LH}$ corresponding to around $1.2 \%$ of oFSH-S17. It therefore remains to be determined whether the BMP15 mutation in heterozygous Inverdale ewes resulted in a greater proportion of follicles maturing to ovulation by altering the responsiveness of developing follicles to FSH or LH or both. In this study, we wished to test the hypothesis that the higher ovulation rate in heterozygous Inverdale ewes is due to more follicles developing an earlier responsiveness to $\mathrm{LH}$ and that the BMP15 mutation did not affect the binding characteristics of the FSHR or the FSH responsiveness of granulosa cells. To test this hypothesis, we examined the effects of FSH at three dose levels and human chorionic gonadotrophin (hCG; as a surrogate for $\mathrm{LH}$ ) at one dose level to stimulate cAMP synthesis in granulosa cells from all nonatretic ovarian follicles $>2.5 \mathrm{~mm}$ diameter from both ovaries of each animal. The FSH binding studies were undertaken on pools of granulosa cells from follicles $\geq 2.5 \mathrm{~mm}$ diameter.

\section{Results}

\section{FSH binding characteristics in I+ and ++ ewes}

The calculated mean \pm S.E.M., $B_{\max }$ for the $\mathrm{I}+(n=3)$ and $++(n=3)$ animals were $18.9 \pm 0.6$ and 23.3 $\pm 2.1 \mathrm{fmol} / \mathrm{mg}$ protein respectively and the $K_{\mathrm{d}}$ were $0.14 \pm 0.01$ and $0.13 \pm 0.01 \mathrm{nM}$ respectively. No significant effects of genotype were observed.

\section{Ovarian characteristics of the I+ and ++ animals used for the cAMP studies}

These are summarised in Table 1. The mean \pm s.E.M. ovarian weights between the genotypes at each stage of the reproductive cycle were not different except during the follicular phase $(++>I+; P<0.05)$. The mean \pm s.E.M. numbers of corpora lutea $(\mathrm{CL})$ were higher in I+ compared to ++ genotype during both the luteal and follicular phases. However, at both stages of the cycle, the mean \pm s.E.M. total weight of luteal tissue per ewe in $\mathrm{I}+$ and ++ genotypes was not significantly different. Irrespective of time of the reproductive cycle, the geometric mean (95\% confidence limits) numbers of follicles $>2.5 \mathrm{~mm}$ diameter in $\mathrm{I}+(\mathrm{N}=41$ animals $)$ was $5.1(4.4,5.9)$ and $7.5(6.4,8.8)$ in the ++ genotype $(N=38$ animals); these values were significantly different $(I+<++; P<0.001)$. Likewise, the mean (95\% confidence limits) overall numbers of non-atretic follicles in $\mathrm{I}+$ and ++ animals were $3.5(2.9,4.2)$ and $5.2(4.3,6.2)$ respectively $(I+<++; P<0.01)$. The proportion of follicles that were nonatretic for each genotype were similar (i.e. $\sim 69 \%$ ) and not different from one another. With respect to time of the reproductive cycle, both the total number of follicles and the number of nonatretic follicles $>2.5 \mathrm{~mm}$ diameter were significantly higher in ++ compared to I + animals during anoestrus (Table 1). However, during the luteal or follicular phases, no differences were noted.

\section{Numbers of follicles with respect to follicular diameter, genotype and time of year}

The geometric mean (95\% confidence limits) for numbers of nonatretic follicles with respect to stage of the reproductive cycle, genotype and follicular diameter are shown in Table 2. During anoestrus, there were significant effects of genotype $(P<0.01)$ and follicular diameter $(P<0.01)$ and there was also a significant genotype by follicular diameter interaction $(P<0.01)$. However, during the luteal or follicular phases, there were no significant effects of follicular diameter or genotype and no interactions were noted.

\section{Effects of FSH on granulosa cell cAMP production with respect to follicular diameter, genotype or stage of reproductive cycle}

When the cAMP responses by granulosa cells over the follicular size ranges $>2.5-3.5,>3.5-4.5$ and $>4.5 \mathrm{~mm}$ diameter were examined overall or with

Table 1 Ovarian characteristics with respect to genotype and stage of reproductive cycle.

\begin{tabular}{|c|c|c|c|c|c|c|}
\hline \multirow[b]{2}{*}{ Ovarian characteristic } & \multicolumn{2}{|c|}{ Anoestrus } & \multicolumn{2}{|c|}{ Luteal phase } & \multicolumn{2}{|c|}{ Follicular phase } \\
\hline & $\mathrm{I}+$ & ++ & $\mathrm{I}+$ & ++ & $\mathrm{I}+$ & ++ \\
\hline Ovarian weight (g) & $1.10 \pm 0.16$ & $1.26 \pm 0.10$ & $3.66 \pm 0.18$ & $4.15 \pm 0.21$ & $2.62 \pm 0.11$ & $3.15^{\dagger} \pm 0.12$ \\
\hline CL no. & & & $3.00 * \pm 0.06$ & $1.90 \pm 0.18$ & $2.50^{\dagger} \pm 0.27$ & $1.70 \pm 0.15$ \\
\hline Total CL weight/ewe (g) & & & $1.39 \pm 0.06$ & $1.40 \pm 0.11$ & $0.82 \pm 0.05$ & $0.81 \pm 0.06$ \\
\hline $\begin{array}{l}\text { Total follicle no }>2.5 \mathrm{~mm} \\
\text { diameter }\end{array}$ & $4.1(3.3,5.1)$ & $7.4^{*}(5.6,9.7)$ & $6.3(\overline{5.1}, 7.7)$ & $8.1(5.7,11.4)$ & $6.4(5.5,7.6)$ & $6.8(5.5,9.3)$ \\
\hline $\begin{array}{l}\text { Non-atretic follicle no } \\
>2.5 \mathrm{~mm} \text { diameter }\end{array}$ & $2.7(2.1,3.5)$ & $6.1^{+}(4.3,8.7)$ & $4.2(3.4,5.1)$ & $4.6(2.8,7.7)$ & $4.9(4.0,6.0)$ & $4.6(3.7,5.8)$ \\
\hline No of ewes & 21 & 18 & 10 & 10 & 10 & 10 \\
\hline
\end{tabular}

Values for ovarian weight, CL number (no), and total CL weight are means \pm s.E.M., whereas the values for follicle number (no) are geometric means with $95 \%$ confidence limits in brackets. For each row and stage of reproductive cycle: ${ }^{*} P<0.01 ;{ }^{\dagger} P<0.05$. 
Table 2 Geometric mean numbers (95\% confidence limits) of nonatretic follicles with respect to stage of the reproductive cycle, follicular diameter and genotype.

\begin{tabular}{|c|c|c|c|c|c|c|}
\hline \multirow{2}{*}{$\begin{array}{l}\text { Follicular diameter } \\
(\mathrm{mm})\end{array}$} & \multicolumn{2}{|c|}{ Anoestrus } & \multicolumn{2}{|c|}{ Luteal phase } & \multicolumn{2}{|c|}{ Follicular phase } \\
\hline & $\mathrm{I}+$ & ++ & $1+$ & ++ & $1+$ & ++ \\
\hline$>2.5-3.5$ & $0.7(0.3,1.1)$ & $3.1^{*}(1.9,4.8)$ & $1.3(0.5,2.4)$ & $1.6(0.9,2.6)$ & $2.0(1.1,3.3)$ & $1.2(0.5,2.1)$ \\
\hline$>3.5-4.5$ & $0.5(0.2,1.0)$ & $0.7(0.3,1.2)$ & $0.9(0.1,2.0)$ & $0.8(0.5,1.6)$ & $1.0(0.5,1.8)$ & $1.1(0.6,1.9)$ \\
\hline$>4.5$ & $1.2(0.8,1.7)$ & $1.6(1.1,2.1)$ & $1.3(0.5,2.5)$ & $1.3(0.6,2.2)$ & $1.5(0.8,2.4)$ & $2.0(1.4,2.7)$ \\
\hline Number & 21 & 18 & 10 & 10 & 10 & 10 \\
\hline
\end{tabular}

$* P<0.001$ for the numbers of follicles $>2.5-3.5 \mathrm{~mm}$ diameter during anoestrus.

respect to each stage of the reproductive cycle, significant effects of FSH dose $(P<0.01)$ but no effects of follicular diameter, genotype or interactions were noted. The mean overall effects of FSH dose on cAMP production by granulosa cells with respect to genotype are shown in Fig. 1.

The proportions of nonatretic follicles $(>2.5 \mathrm{~mm}$ diameter) with granulosa cells capable of producing $\geq 5 \mathrm{pmol}$ cAMP/million cells with respect to genotype and stage of the reproductive cycle were also investigated. During anoestrus, luteal and follicular phases, the respective proportions of follicles from I+ animals producing $\geq 5 \mathrm{pmol}$ cAMP/million granulosa cells in response to $\mathrm{FSH}$ were 23/61 (38\%), 25/44 (57\%) and $31 / 43(72 \%)$ and for the ++ ewes they were $31 / 102$ $(30 \%), 24 / 43(56 \%)$ and 36/51 (71\%). The highest proportion of follicles producing $\geq 5$ pmol cAMP/ million granulosa cells was found during the follicular phase and the lowest during anoestrus for both genotypes. However, when each of these data sets was tested by $\chi^{2}$ analysis no genotype effects were noted either overall or at any stage of the reproductive cycle.

\section{Effects of hCG on granulosa cell cAMP production with respect to follicular diameter, genotype or stage of reproductive cycle}

Less than $4 \%$ of $\mathrm{I}+(4 / 174)$ and $++(5 / 152)$ follicles $\leq 2.5 \mathrm{~mm}$ in diameter were found to have granulosa cells capable of producing $\geq 5 \mathrm{pmol}$ cAMP/million cells (data not shown). Therefore, the hCG responsiveness was examined in more detail from follicles $>2.5 \mathrm{~mm}$ diameter. When the overall effects of hCG on granulosa cell cAMP production were examined with respect to follicular diameter and genotype (stages of the reproductive cycle pooled) significant effects of genotype $(P<0.05)$ and follicular diameter $(P<0.001)$ but no interactions were noted (Fig. 2). During both anoestrus and the luteal, but not follicular phases, significant effects of genotype were noted (anoestrus, $P<0.05$; luteal phase, $P<0.02$ ). At all reproductive stages, significant effects of follicular diameter on hCG-induced cAMP responsiveness were noted $(P<0.01)$.
The proportions of nonatretic follicles with granulosa cells producing $\geq 5 \mathrm{pmol} \mathrm{cAMP} / \mathrm{million}$ cells with respect to genotype and stage of the reproductive cycle were also investigated. During anoestrus, luteal and follicular phases, the respective proportions of follicles from I+ animals producing $\geq 5 \mathrm{pmol}$ cAMP/million granulosa cells were 20/60 (33\%), 23/44 (52\%) and $24 / 43(56 \%)$ and for the ++ ewes they were $18 / 102$ $(18 \%), 10 / 43(23 \%)$ and $24 / 51(47 \%)$. When each of these data sets were tested by $\chi^{2}$ analysis, significant genotype effects were noted overall $(P<0.01)$, during anoestrus $(P<0.01)$ and the luteal phase $(P<0.05)$ but not during the follicular phase.

\section{Discussion}

The ovulation rates and luteal characteristics of the Inverdale ewes in the present study were similar to those previously reported by Shackell et al. (1993). While I+ ewes had an average ovulation rate approximately one higher than the wild-types, the total mass of luteal tissues was not different between the genotypes. This arose despite the fact that there were no differences in the number or range of follicular diameters in nonatretic

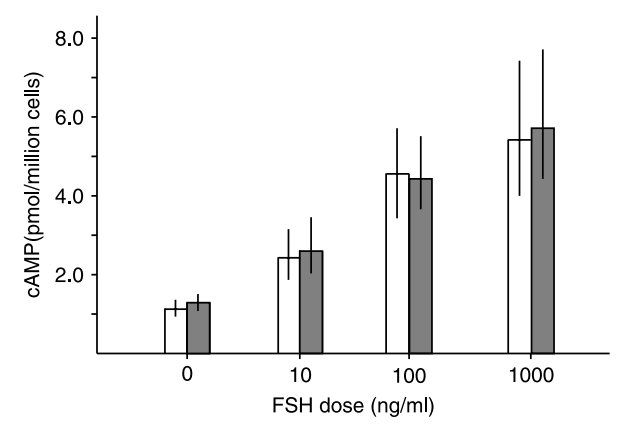

Figure 1 Effect of dose of FSH on granulosa cell cAMP production with respect to genotype. The histograms are geometric means and vertical bars represent $95 \%$ confidence limits. The white and gray bars represent the overall averaged granulosa cell responses from nonatretic follicles $>2.5 \mathrm{~mm}$ diameter from $41 \mathrm{I}+$ ewes and $38++$ wildtype animals respectively. There was a significant effect of FSH dose $(P<0.01)$ but no effects of follicular diameter or genotype and no interactions. 


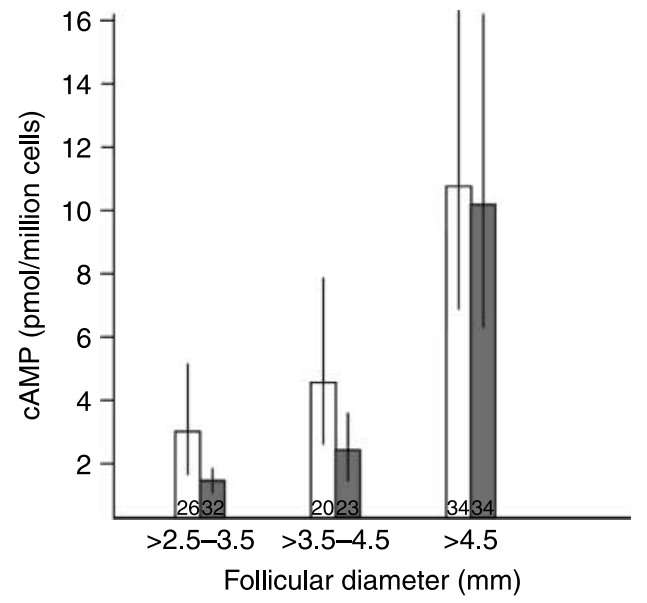

Figure 2 Effect of hCG on granulosa cell cAMP production with respect to follicular diameter and genotype. White histograms represent geometric means for I+ and grey histograms the wild-type ewes. Vertical lines represent the $95 \%$ confidence limits and the numbers inside the histograms represent the number of sheep. There were significant main effects of follicular diameter $(P<0.001)$ and genotype $(P<0.05)$ and no interactions noted.

follicles present during either the luteal or follicular phases of the oestrous cycle. The only exception noted in follicular activity was observed for the total number and number of nonatretic $>2.5-3.5 \mathrm{~mm}$ diameter follicles during anoestrus $(++>\mathrm{I}+)$. Overall, these findings confirm that there is no significant difference in size distribution of nonatretic follicles $>2.5 \mathrm{~mm}$ diameter favouring I+ over ++ ewes. Previous studies show that treatment of ewes with exogenous FSH can significantly increase the number of nonatretic follicles $>4.5 \mathrm{~mm}$ diameter without altering the total number of antral follicles (McNatty et al. 1992).

While differences in plasma FSH concentrations have not been reported for I+ ewes, earlier studies by Shackell et al. (1993) suggest that I+ animals contained antral follicles with granulosa cells that potentially are more sensitive to FSH. Such an interpretation is consistent with the in vitro results with rat granulosa cells showing that BMP15 can inhibit FSHR mRNA activity (Shimasaki et al. 2004) and with I+ ewes having reduced levels of BMP15 (Galloway et al. 2000) so that I+ granulosa cells will be more responsive to FSH. However, from a detailed evaluation of the responsiveness of granulosa cells from all individual nonatretic follicles, no genotype effect was observed for FSH responsiveness in granulosa cells. In the present study, a highly purified FSH preparation, devoid of LH contamination, was used and there was no evidence to suggest that the proportion of follicles responding to any FSH dose differed between the genotypes. Indeed, the only effect noted for FSH was that of dose; the higher the dose, the greater the cAMP response. Therefore, it is likely that the genotype effect observed at a high dose of FSH (1000 ng/ml) by Shackell et al. (1993) was due to the $\mathrm{LH}$ contamination in the FSH preparation. For example, when $1000 \mathrm{ng} / \mathrm{ml}$ of FSH was added to the culture, the LH contamination would have been $12 \mathrm{ng} / \mathrm{ml}$. In addition to the absence of a genotype effect with respect to FSH-induced cAMP synthesis, no genotype differences were noted with respect to the FSH binding characteristics in granulosa cells from follicles $\geq 2.5 \mathrm{~mm}$ diameter. However, it is important to note, when collecting cells for this study, that no attempt was made to distinguish between nonatretic or atretic follicles. Moreover, neither the binding studies nor those examining cAMP responses in individual follicles rule out the possibility that there are effects of the BMP15 mutation on FSH responsiveness in smaller diameter (i.e. $\leq 2.5 \mathrm{~mm}$ ) follicles. However, if this was the case, it was not reflected in any differences in cAMP responses of granulosa cells of these small follicles (data not shown) or any differences in the size distributions of antral follicles which might be anticipated if there were differences in sensitivities to FSH. In the Shackell et al. (1993) study, more small antral follicles between 1.0 and $2.5 \mathrm{~mm}$ diameter were observed in $\mathrm{I}+$ than in ++ ewes but this was not the case in the present study (data not shown).

The key finding from the present study was that I+ ewes have a greater proportion of nonatretic follicles $>2.5 \mathrm{~mm}$ diameter with granulosa cells responsive to hCG/LH than in wild-type ewes. Although significant, the effect was small and only observed after screening granulosa cells from all individual non-atretic follicles $>2.5 \mathrm{~mm}$ diameter, as not all were responsive to hCG. It is likely that this genotype effect would have been masked if granulosa cell from all nonatretic follicles were pooled. It is perhaps not surprising that the effect is small given that the ovulation rate difference between the genotypes is only $\sim 1$. It is evident that the overall genotype effect for the hCG/LHinduced CAMP responsiveness was due to a greater proportion of non-atretic follicles between $>2.5$ and $4.5 \mathrm{~mm}$ in I+ ewes having granulosa cells responding to hCG relative to that in ++ animals. With respect to stage of the reproductive cycle, this genotype effect was noted during anoestrus and the luteal phase but not follicular phase. Our interpretation of these data is that during the luteal phase and anoestrus, the I+ effect influences the number of follicles $>2.5 \mathrm{~mm}$ diameter capable of responding to $\mathrm{hCG} / \mathrm{LH}$, whereas by the follicular phase all the follicles committed to ovulate have been selected so that the probability of observing a genotype difference on a very small population of follicles over a short window of time is low.

It has been shown in rat granulosa cells, that BMP15 inhibits FSH-induced expression of LHR (Shimasaki et al. 2004). The present study showed no difference in the FSHR characteristics nor the cAMP responsiveness of granulosa cells to endogenous $\mathrm{FSH}$ between $\mathrm{I}+$ and ++ animals. However, it is possible that FSH and 
BMP15 crosstalk between the two different signalling pathways, downstream of the production of cAMP. Lowering the amount of bioactive BMP15, as is the case in I+ animals, may alter this cross talk resulting in the attainment of the LHR in an increased proportion of follicles from I+ animals.

In summary, from FSH-receptor binding analyses and using a highly purified oFSH preparation to assess granulosa cell cAMP responses from individual follicles, no evidence was found to suggest that heterozygous Inverdale ewes have a higher ovulation rate as a consequence of enhanced follicular sensitivity to FSH. By contrast, using hCG as a surrogate for $\mathrm{LH}$, a higher proportion of follicles in heterozygous Inverdale ewes contained granulosa cells capable of producing high levels of cAMP compared to the wild-type. It is concluded that the mutation in the BMP15 gene in heterozygous Inverdale ewes leads to an earlier acquisition of $\mathrm{LH}$ responsiveness in a greater proportion of follicles and this accounts for the small but significantly higher ovulation rate in these animals.

\section{Materials and Methods}

\section{Animals}

All experiments were performed with approval of the Animal Ethics Committee of the Wallaceville Animal Research Centre in accordance with the Animal Welfare Act Regulations of New Zealand. All animals had access to pasture and water ad libitum. The animals in this study were 5-9 year old heterozygous Inverdale ewes derived from mating known carrier Romney rams with control Romney ewes $(I+)$, whereas the wild-types $(++)$ were generated by mating control Romney rams and ewes. The time between recovery of ovaries and initiation of follicular dissection was $<30 \mathrm{~min}$.

In the first study, where the aim was to measure FSH binding characteristics in granulosa cells, ovaries of $55 \mathrm{I}+$ and $52++$ ewes were recovered from the slaughterhouse. In the second experiment, ovaries were recovered from $21 \mathrm{I}+$ and $18++$ ewes during anoestrus (November-December), $10 \mathrm{I}+$ and $10++$ ewes from days 10 to 12 of a $\mathrm{PGF}_{2 \alpha}$-induced luteal phase during the breeding season (June) and in $10 \mathrm{I}+$ and $10++$ ewes at $24 \mathrm{~h}$ after a $\mathrm{PGF}_{2 \alpha}$-induced follicular phase during the breeding season (June-July).

\section{FSH and $L H$ reagents}

An in-house highly purified oFSH preparation (oFSH Wal) was used for all studies herein. The oFSH was purified from ovine pituitary glands using tryazine-dye chromatography, hydrophobic interaction chromatography and gel filtration as described elsewhere (Moore et al. 1997, Fidler et al. 2003). The oFSH preparation was $>90 \%$ pure as determined by gel exclusion chromatography, PAGE and HPLC ion exchange chromatography with a bioactivity of $1.4 \times$ USDA-oFSH19-SIAFP RP2 or $33000 \mathrm{IU} / \mathrm{mg}$ when the second human FSH International Reference Preparation 78/549 was used as a standard in a radioreceptor assay. The level of LH contamination was $<0.002 \%$ as determined by bioassay.

The $\mathrm{LH}$ preparation used in all studies was the hCG preparation (CR121; $13450 \mathrm{IU} / \mathrm{mg}$; NICHD, Bethesda, MD, USA).

\section{Ovarian collection for the FSH binding studies}

The method used for the recovery of granulosa cells were similar to that described elsewhere (McNatty et al. 1989). Briefly, ovaries were collected and dissected in saline $(0.9 \%)$ containing $20 \mathrm{mM}$ Hepes buffer $(\mathrm{pH}$ 7.4). Thereafter, all follicles $\geq 2.5 \mathrm{~mm}$ diameter were dissected and the granulosa cells removed with a platinum loop. The granulosa cells recovered from all isolated and selected follicles were pooled with respect to genotype, centrifuged at $450 \mathrm{~g}$ at $4-6{ }^{\circ} \mathrm{C}$ for $20 \mathrm{~min}$ and the pellets resuspended in Tris buffer (i.e. 0.05 $\mathrm{M}$-Tris- $\mathrm{HCl}$ buffer containing $0.02 \mathrm{M}$-sucrose and $5 \mathrm{mM}$ $\mathrm{MgCl}_{2}(\mathrm{pH} 7.5)$ to a final concentration of $25 \times 10^{6} \mathrm{cells} / \mathrm{ml}$. These cell suspensions were then added in $0.2 \mathrm{ml}$ aliquots to assay tubes, capped and stored at $-70^{\circ} \mathrm{C}$ until the binding studies were undertaken. For each FSHR binding study, 15-20 animals per genotype were required to obtain sufficient number of cells and the collections were replicated for each genotype thrice.

\section{FSHR binding studies}

The equilibrium binding studies were similar to those reported by McNatty et al. (1989) except that the in-house highly purified $\mathrm{FSH}$ preparation oFSH-Wal was used as the ligand. The incubations of ${ }^{125} \mathrm{I}-\mathrm{oFSH}(45 \mu \mathrm{Ci} / \mu \mathrm{g})$ with granulosa cells were performed at $37^{\circ} \mathrm{C}$ for $75 \mathrm{~min}$ to achieve equilibrium. The maximum bindability of the radiolabelled $\mathrm{FSH}$ to the granulosa cell preparations was $\sim 15 \%$. Duplicate measurements were made at each binding point. Non-specific binding was determined using excess unlabelled Gonadotraphon FSH (Paines \& Byrne Ltd, Greenford, UK). The amount of specifically bound ${ }^{125} \mathrm{I}$-oFSH in c.p.m. was calculated by subtracting nonspecific binding from the total amount of bound FSH. Woolf plots (i.e. free hormone/bound hormone versus free hormone; Keightley \& Cressie 1980) were generated by using a standard amount of ${ }^{125} \mathrm{I}-\mathrm{OFSH} \quad(\sim 3 \mathrm{ng})$ and increasing amounts of unlabelled oFSH (i.e doubling amounts from 2 to $128 \mathrm{ng}$ ). The binding capacity $B_{\max }$ was derived from the slope of the fitted line (i.e. slope $=1 / B_{\max }$ ) and the equilibrium $K_{\mathrm{d}}$ calculated from the $B_{\max } \times$ intercept.

\section{Recovery and preparation of granulosa cells for cAMP studies and assay}

The ovarian weights and numbers and weights of $\mathrm{CL}$ were recorded. Thereafter, all follicles $>1.0 \mathrm{~mm}$ were dissected at room temperature in DMEM with $20 \mathrm{mM}$ Hepes buffer, $0.2 \mathrm{mM}$ 3-isobutyl-methylxanthine (Sigma Chemical Co.) and $0.1 \%$ $(\mathrm{w} / \mathrm{v})$ BSA (>97\% pure; ImmunoChemical Products Ltd, Auckland, New Zealand). Nonatretic follicles were those defined as having a vascularised theca interna, no debris in 
follicular fluid, $\geq 25 \%$ of the maximum number of granulosa cells for a given size and an oocyte of healthy appearance (McNatty et al. 1986). An atretic follicle was so defined if one or more of the above criteria were not satisfied. Once recovered, the cells from individual follicles were centrifuged at $450 \mathrm{~g}$ at $4-6{ }^{\circ} \mathrm{C}$ for $5 \mathrm{~min}$ and the pellets resuspended in the aforementioned medium so that a final concentration of 60000 cells per culture was achieved. As many follicles between $>1.0-2.5 \mathrm{~mm}$ diameter had insufficient granulosa cells for evaluating their cAMP responses to both FSH and hCG, the results from here onwards are described only for individual follicles $>2.5 \mathrm{~mm}$ diameter. The cells from these follicles were then incubated in 48-well culture plates with or without FSH $(10,100$ or $1000 \mathrm{ng} / \mathrm{ml})$ or hCG $(1000 \mathrm{ng} / \mathrm{ml})$ in a final volume of $600 \mu \mathrm{l}$ at $37^{\circ} \mathrm{C}$ in a water bath for $45 \mathrm{~min}$. Subsequently, the cultures were heated at $80{ }^{\circ} \mathrm{C}$ for $15 \mathrm{~min}$. Samples were stored at $-20^{\circ} \mathrm{C}$ until assayed for CAMP. The cAMP assay was similar to that described by Jolly et al. (1997) except that an in-house rabbit anti 0, 2-monosuccinyl-adenosine-3', $5^{\prime}$-cyclic monophosphate antibody was employed and separation of bound from free cAMP with an in-house sheep anti-rabbit second antibody was followed by the addition of 2.5 volumes of $14 \%$ $(\mathrm{w} / \mathrm{v})$ polyethylene glycol 8000 (Union Carbide Corp., Danbury, CN, USA). The in-house primary antibody to cAMP cross-reacted $9 \%$ with dibutyryl cAMP and $<0.0014 \%$ with cGMP and $\leq 0.0001 \%$ with AMP, ADP or ATP. The detection limit was $0.2 \mathrm{pmol} / \mathrm{million}$ cells and the intra- and interassay coefficients of variation were both $<9 \%$ respectively.

\section{Statistical procedures}

The proportions of follicles with granulosa cells expressing high ( $\geq 5 \mathrm{pmol} / \mathrm{million}$ cells) or low levels of cAMP ( $<5 \mathrm{pmol} /$ million cells) in response to the highest dose of FSH or hCG during anoestrus, the luteal or follicular phase or overall were examined by $\chi^{2}$ analyses. cAMP responses of cells to $\mathrm{FSH}$ or hCG from each ewe were examined with respect to genotype, FSH dose, reproductive status or follicular size and potential interactions by ANOVA after all cAMP data were first normalised by Ln transformation. Where appropriate, the post hoc comparisons were made using the Bonferroni test.

\section{Declaration of interest}

The authors declare that there is no conflict of interest that could be perceived as prejudicing the impartiality of the research reported.

\section{Funding}

This work was supported by funding by the New Zealand Foundation for Research Science and Technology (C10X0308).

\section{Acknowledgements}

We wish to acknowledge the assistance of Doug Jensen on the farm staff at the former AgResearch Wallaceville Animal Research Centre, Upper Hutt, New Zealand and the assistance of Dr George Davis, AgResearch Invermay Agricultural Centre, Mosgiel, New Zealand for the supply of Inverdale ewes of known genotype.

\section{References}

Bodin L, Di Pasquale E, Fabre S, Bontoux M, Monget P, Persani L \& Mulsant P 2007 A novel mutation in the bone morphogenetic protein 15 gene causing defective protein secretion is associated with both increased ovulation rate and sterility in Lacaune sheep. Endocrinology 148 393-400.

Fidler AE, Lin JS, Lun S, Ng Chie W, Western A, Stent V \& McNatty KP 2003 Production of biologically active tethered ovine $\mathrm{FSH} \beta \alpha$ by the methylotrophic yeast Pichia pastoris. Journal of Molecular Endocrinology 30 213-225.

Galloway SM, McNatty KP, Cambridge LM, Laitinen MPE, Juengel JL, Jojiranta TS, McLaren RJ, Luiro K, Dodds KG, Montgomery GW et al. 2000 Mutations in an oocyte-derived growth factor (BMP15) cause increased ovulation rate and infertility in a dosage-sensitive manner. Nature Genetics 25 279-283.

Hanrahan JP, Gregan SM, Mulsant P, Mullen M, Davis GH, Powell R \& Galloway SM 2004 Mutations in the genes for oocyte derived growth factors GDF9 and BMP15 are associated with both increased ovulation rate and sterility in Cambridge and Belclare sheep (Ovis aries). Biology of Reproduction 70 900-909.

Jolly PD, Tisdall DJ, De'ath G, Heath DA, Lun S, Hudson NL \& McNatty KP 1997 Granulosa cell apoptosis, aromatase activity, cyclic adenosine $3^{\prime}, 5^{\prime}$-monophosphate response to gonadotropins and follicular fluid steroid levels during spontaneous and induced follicular atresia in ewes. Biology of Reproduction 56 830-836.

Juengel JL, Hudson NL, Heath DA, Smith P, Reader KL, Lawrence SB, O'Connell AR, Laitinen MP, Cranfield M, Groome NP et al. 2002 Growth differentiation factor 9 and bone morphogenetic protein 15 are essential for ovarian follicular development in sheep. Biology of Reproduction 67 1777-1789.

Keightley DD \& Cressie NAC 1980 The Wolf plot is more reliable than the Scatchard plot in analysing data from the hormone receptor assays. Journal of Steroid Biochemistry 13 1317-1323.

Martinez-Royo A, Jurado JJ, Smulders JP, Marti JI, Alabart JL, Roche A, Fantova E, Bodin L, Mulsant P, Serrano M et al. 2008 A deletion in the bone morphogenetic protein 15 gene causes sterility and increased prolificacy in Rasa Araganosa sheep. Animal Genetics 39 294-297.

McNatty KP, Lun S, Heath DA, Ball K, Smith P, Hudson NL, McDiarmid J, Gibb M \& Henderson KM 1986 Differences in ovarian activity between Booroola $\times$ Merino ewes which were homozygous, heterozygous and non-carriers of a major gene influencing their ovulation rate. Journal of Reproduction and Fertility 77 193-205.

McNatty KP, Lun S, Heath DA, Hudson NL, O'Keeffe LE \& Henderson KM 1989 Binding characteristics of ${ }^{125}$ I-labelled human FSH to granulosa cells from Booroolla ewes which were homozygous, heterozygous or non-carriers of a major gene(s) influencing their ovulation rate. Journal of Reproduction and Fertility 86 27-38.

McNatty KP, Hudson NL, Heath DA, Shaw L, Blay L, Berry L \& Lun S 1992 Effect of chronic FSH administration on ovarian follicular development, ovulation rate and corpora lutea formation in sheep. Journal of Endocrinology 138 315-325.

McNatty KP, Lawrence S, Groome NP, Meerasahib MF, Hudson NL, Whiting L, Heath DA \& Juengel JL 2006 Oocyte signalling molecules and their effects on reproduction in ruminants. Reproduction, Fertility, and Development 18 403-412.

Monteagudo LV, Ponz R, Tejedor MT, Lavina A \& Sierra I 2009 A 17 bp deletion in the bone morphogenetic protein 15 (BMP15) gene is associated to increased prolificacy in the Rasa Araganosa sheep breed. Animal Reproduction Science 110 139-146.

Moore RK \& Shimasaki S 2005 Molecular biology and physiological role of the oocyte factor, BMP15. Molecular and Cellular Endocrinology 234 $67-73$. 
Moore LG, Ng Chie W, Lun S, Lawrence SB, Young W \& McNatty KP 1997 Follicle stimulating hormone in the brushtail possum (Trichosaurus vulpecula): purification, characterization and radioimmunoassay. General and Comparative Endocrinology 106 30-38.

Shackell GH, Hudson NL, Heath DA, Lun S, Shaw L, Condell L, Blay LR \& McNatty KP 1993 Plasma gonadotropin concentrations and ovarian characteristics in Inverdale ewes that are heterozygous for a major gene (Fec $\left.X^{\prime}\right)$ on the $X$ chromosome that influences ovulation rate. Biology of Reproduction 48 1150-1156.
Shimasaki S, Moore RK, Otsuka F \& Erickson GF 2004 The bone morphogenetic protein system in mammalian reproduction. Endocrine Reviews 25 72-101.

Received 22 April 2009

First decision 20 May 2009

Accepted 17 June 2009 